\title{
Slawomir Czapnik
}

Uniwersytet Opolski

e-mail: slawomir.czapnik@o2.pl

\section{Rozważny i romantyczny? \\ Wizje socjalizmu w dziennikach \\ Ernesto Che Guevary i Mieczysława F. Rakowskiego}

Słowa kluczowe: Ernesto Che Guevara, Mieczysław F. Rakowski, socjalizm, imperializm, rewolucja

\section{Wprowadzenie}

Pomysł porównywania - wyrażonych wprost i rekonstruowanych - wizji socjalizmu, które można odnaleźć na tysiącach stron dzienników zapisanych przez Ernesto Che Guevarę i Mieczysława F. Rakowskiego, wydaje się karkołomny, jeśli nie poroniony. Jeżeli pozostawić na boku postmodernistyczne gry uznające mieszanie wszystkiego ze wszystkim za cnotę, a przynajmniej coś zabawnego dla autora (a niekiedy i czytelnika, zwłaszcza - zblazowanego czytelnika), trudno o dwie diametralnie odmienne i nieporównywalne postacie. Abstrahując od całkowicie tu nieistotnych dywagacji, kiedy i z jakich względów nazywali oni siebie marksistami czy też komunistami - a byłemu naczelnemu „Polityki” pewnie przez lata najbliżej było do socjaldemokracji - warto się pokusić o sprawdzenie, czy i w jakiej mierze prezentowane przez nich rozumienie socjalizmu jest aktualne obecnie, w drugiej dekadzie XXI stulecia. Wymaga to oddzielenia elementów uniwersalnych, ogólnoludzkich, pokonujących bariery czasu i przestrzeni, od elementów przygodnych i lokalnych, stanowiących odzwierciedlenie świadomości 
osób doświadczających bytu w specyficznych warunkach historycznych. Innymi słowy, przyjęcia ogólnych dyrektyw materializmu historycznego.

Jak czytamy w Ideologii niemieckiej,

[w]ytwarzanie idei, wyobrażeń, świadomości splata się zrazu bezpośrednio z materialną działalnością ludzi i ich materialnymi stosunkami wzajemnymi [materieller Verkehr der Menschen], stanowi język rzeczywistego życia. [...] Ludzie są wytwórcami swoich wyobrażeń, idei itd., ale ludzie rzeczywiści, działający, uwarunkowani przez określony rozwój ich sił wytwórczych i odpowiadających tym siłom stosunków aż do najwyższych form włącznie. Świadomość nie może być nigdy niczym innym jak świadomym bytem, a byt ludzi to ich rzeczywisty proces życiowy'.

Poza sporem pozostaje, że proces życiowy latynoamerykańskiego rewolucjonisty zabitego przed czterdziestym rokiem życia - niestrudzonego bojownika walki z amerykańskim imperium, którego wizerunek jest od dziesięcioleci częścią kultury popularnej, oraz wytrawnego środkowoeuropejskiego polityka i dziennikarza, rzecznika zbliżenia z kapitalistycznym Zachodem (zwłaszcza z Republiką Federalną Niemiec), dążącego do rozluźnienia więzów łączących jego kraj z imperium radzieckim, był diametralnie odmienny. Pierwszy żył i zginął, wyznając zasadę Socjalizm albo śmierć!! (Socialismo o muerte!), drugi przez lata walczył o socjalizm z ludzka twarza, a potem, w obliczu coraz bardziej oczywistej zapaści systemu - stał się jego grabarzem i promotorem przemian rynkowych zazdrośnie spoglądającym na zachodnioeuropejskie państwo dobrobytu. Pierwszy najlepiej czuł się w ogniu walki rewolucyjnej, wieczny guérillero heroico (tak brzmi tytuł słynnego zdjęcia autorstwa Alberto Kordy), który zapłacił życiem za brak zręczności politycznej, drugi mozolnie piął się po szczeblach kariery partyjno-państwowej, piastując najwyższe stanowiska w sytuacji, kiedy realny socjalizm chylił się ku upadkowi. Pierwszy dla milionów ludzi był i pozostaje natchnieniem, symbolem romantycznego, na wskroś prometejskiego buntu, drugiego zwykle chwalono za pragmatyzm, umiar i rzeczowość.

Dookreślenia wymaga pojmowanie socjalizmu rozumianego jako ramy poznawczo-wartościujące, na które składa się odraza wobec społecznie uwarunkowanej niesprawiedliwości, pasja odsłaniania kłamstw skrywających odpowiedzialność za ludzką niedolę, a także wyczulenie na wszelkie próby ograniczania ludzkiej wolności, a zatem zgoła Marksowskie przekonanie o nieskończoności i niespełnieniu ludzkich możliwości². Jak zauważa Zygmunt Bauman, „[w]ysiłek zbudowania socjalistycznego

1 Cyt. za: E. Fromm, Kryzys psychoanalizy. Szkice o Freudzie, Marksie i psychologii społecznej, tłum. W. Brydak, Poznań 2000, s. 166-167.

2 Z. Bauman, K. Tester, O pożytkach z watpliwości. Rozmowy z Zygmuntem Baumanem, tłum.

E. Krasińska, Warszawa 2003, s. 38. 
społeczeństwa jest w ostatecznym rachunku próbą wyzwolenia natury ludzkiej deprawowanej i upokarzanej przez społeczeństwo klasowe”, a ,przekonanie o wykonalności socjalistycznego projektu opiera się właśnie na nadziei, że w odpowiednich warunkach ludzie przestaną być takimi, jakich ich aktualnie znamy i zdajemy się od wieków znać"3. W skrócie: socjalizm to utopia w działaniu, postawa nacechowana moralną wrażliwością oraz niezgodą na zło i cierpienie.

Poniższe rozważania składają się z czterech rozdziałów. Najpierw próbuje się porównać Rakowskiego i Guevarę do głównych postaci klasycznej powieści Miguela de Cervantesa. Następnie przechodzi się do metod działania omawianych postaci. Trzecia część opisuje stosunek Rakowskiego i Guevary do imperiów i imperializmu, nie tylko kapitalistycznych, ale i komunistycznego - Związku Radzieckiego. Ostatni rozdział próbuje unaocznić różnice charakterologiczne, które wyłaniają się z dzienników obu mężczyzn, chcąc je umiejscowić w kategoriach ideologicznych.

\section{Don Kichot i Sancho Pansa}

Dalszy wywód warto ustrukturyzować, odwołując się do poczynionego przez Waltera Benjamina rozróżnienia dwóch rodzajów opowieści: opowieści żeglarzy i opowieści chłopów ${ }^{4}$. Pierwsze mówią o sprawach niezwykłych i zaskakujących, których oko człowieka nie widziało, o potworach, mężnych wojownikach i obłudnych niegodziwcach w skrócie: o ludziach odmiennych od słuchaczy. Ich bohaterowie dokonują rzeczy, które wzbudzają podziw i onieśmielają. Opowieści chłopów mówią o zwykłych sprawach, o powtarzającym się cyklu pór roku lub też codziennych monotonnych zajęciach domowych bądź gospodarskich. Te sprawy są pozornie znane, bowiem niekiedy ich bliskość, powszedniość uniemożliwia zobaczenie ich takimi, jakimi one są w rzeczywistości. Ta zwyczajność jest niekiedy zwodnicza, ukrywając wiele zagadek.

Guevera, nieustraszony obrońca uciśnionych i ubogich, był wręcz stworzony używając modnego obecnie języka, genetycznie zaprogramowany - by snuć opowieści awanturniczych podróżników, żeglarzy gnanych od portu do portu przez nieznaną (zwykle fatalną) siłę. Pochodził z rodziny arystokratycznej, był potomkiem ostatniego hiszpańskiego wicekróla Peru ${ }^{5}$. Dziedzictwo Che, którego przodek pojawił się skądinąd w pismach Karola Marksa, jest osobliwe:

dziadek, syn Irlandczyka i Baskijki, był poszukiwaczem złota w Kalifornii - poznał tam niejaką Albertynę Ugalde, która w wieku dwudziestu lat, w roku 1871, zmarła

3 Z. Bauman, Socjalizm. Utopia w działaniu, tłum. M. Bogdan, Warszawa 2010, s. 113, 152.

4 Z. Bauman, 44 listy ze świata płynnej nowoczesności, tłum. T. Kunz, Kraków 2011, s. 8-10.

5 J.G. Castañeda, Che Guevara, tłum. J. Mikos, Warszawa 2007, s. 15. 
na żółtą febrę. Silnie wybuchowa mieszanka krwi irlandzko-baskijskiej płynęła więc w żyłach tego potomka dobrej rodziny ${ }^{6}$.

Warto do tego dodać, że już nastoletni Guevara - chory na astmę dręczącą go do ostatnich dni - wykazywał wręcz straceńczą fantazję, stawał choćby na rękach na parapecie balustrady mostu i utrzymywał się przez jakiś czas w tej pozycji dwadzieścia metrów nad kłębiącą się wodą ${ }^{7}$.

Rakowski pochodził z chłopskiej rodziny w dawnym zaborze pruskim, a konkretnie - z gospodarnej Wielkopolski. Wojna odcisnęła na nim mocne piętno, jego ojciec został zamordowany przez Niemców. W młodości przyszły dziennikarz zarabiał na życie jako robotnik, w ostatnim roku wojny znalazł się w ludowym wojsku, gdzie służył w stopniu oficera do 1949 roku$^{8}$. Według Adama Krzemińskiego jego biografia była znamienna dla całego pokolenia:

Odzwierciedliła to, co najlepsze w pokoleniu rozbitym przez wojnę, odartym ze złudzeń, świadomym zniszczeń i akceptującym powojenne zmiany - w warunkach wojny domowej, radzieckich czołgów i stalinizmu, awansującym dzięki nowej władzy, a jednak pod wpływem odwilży po śmierci tyrana 1953 i szoku tajnej mowy Chruszczowa na XX zjeździe KPZR, świadomie uczestniczącym w demokratyzacji i modernizacji PRL, otwieraniu Polski na świat ${ }^{9}$.

Wydaje się, że ten chłopski, rozsądny rys doskonale wyjaśnia postępowanie Rakowskiego - upór i konsekwencje w dążeniu do celu, a zarazem zgodę na warunki, których zmienić i tak nie można (a przynajmniej tak się wydaje).

Pod pewnymi względami najlepiej nastrój dzienników Guevary i Rakowskiego oddaje metafora Don Kichota i Sancho Pansy, przy czym nie ma ona na celu ośmieszenia, zdeprecjonowania bądź wywyższenia któregokolwiek z nich kosztem drugiego. Zarówno przemyślny szlachcic z La Manchy, jak i jego wierny kompan to postacie na wskroś socjalistyczne - dwaj egalitaryści w świecie feudalnej nierówności i niesprawiedliwości. W szaleństwie Don Kichota jest metoda - nazwijmy ją metodą utopijnego realizmu. Don Kichot potrafi wykazać względność istniejących realiów, uwalniając potencjał krytyczny, ujawnia bowiem ich niekompletność, podważa ich absolutną oczywistość (stanowiącą rzekomy wynik wyroków boskich, wiecznej tradycji, niezmiennych praw ludzkiej natury czy też bezosobowych praw rynku), czyli koniec końców uprawomocnia myślenie o al-

6 J. Cormier, H. Guevara Gadea, A.G. Jimenez, Che Guevara, tłum. W. Sadkowski, Warszawa 2004, s. 17.

7 Ibidem, s. 22.

8 A. Friszke, Diariusz Rakowskiego, „Polityka”, dodatek „Niezbędnik inteligenta”, 7 września 2005 r.

9 A. Krzemiński, Mój Rakowski, „Polityka”, 9 listopada 2008 r. 
ternatywnych rozwiązaniach jątrzących problemów teraźniejszości. W nawet najbardziej niesprzyjających okolicznościach, pomimo rozlicznych przeciwności losu i wcześniejszych niepowodzeń, zachowuje on nadzieję, która „dostarcza brakującego ogniwa łączącego interesy praktyczne z teoretycznymi, ponieważ jest z natury krytyczna wobec rzeczywistości, w której jest zakorzeniona, rozszerzając z tego tytułu pojęcie realizmu na tyle, by ogarnęło pełny zestaw możliwych opcji”" ${ }^{10}$. Cervantes z pewnością mógłby przypisać swemu bohaterowi najsłynniejsze zapewne zawołanie bojowe Che: „Bądźmy realistami. Żądajmy niemożliwego" "1. Poza sporem pozostaje, że latynoamerykański rewolucjonista dokonał rzeczy, które wydawały się uprzednio niemożliwe, co doskonale pokazuje książka Paula J. Dosala ukazująca Che jako El Comandante, żołnierza, dowódcę i stratega walki partyzanckiej ${ }^{12}$. Guevara przyczynił się do wyzwolenia Kuby spod dominacji Stanów Zjednoczonych - był głównym architektem zwycięstwa powstania i uratował rebeliancką armię Fidela Castro od zniszczenia. Wśród czytelników pism i przemówień Guevary o guérilli był prezydent John F. Kennedy namawiający do ich lektury inne osoby. Kennedy i jego następca, Lyndon B. Johnson, rozwinęli sieć jednostek specjalnych mających zwalczać partyzantkę w krajach Trzeciego Świata. Błyskotliwy, innowacyjny dowódca dokonał czynów wpływających na świat w równie doniosły sposób, co oficerowie wyższej rangi lub kierujący większymi armiami.

Wpływ Che na Amerykę Łacińską, Stany Zjednoczone i świat był o wiele większy niż rozmiar batalii, które wygrał i przegrał. Miał on nade wszystko charakter symboliczny - kiedy pojawił się w Boliwii, stając na czele wyizolowanego czterdziestoosobowego oddziału, prezydent Johnson uznał ten kraj za główny przedmiot troski w sferze bezpieczeństwa, a Stany Zjednoczone wcześniej i później wydały setki milionów dolarów na zwalczanie ruchów partyzanckich niemal w każdym kraju regionu. USA prowadziły za pośrednictwem swych boliwijskich sojuszników wojnę przeciw jednemu człowiekowi, a nie żadnemu krajowi, bowiem mistrz działań partyzanckich w Ameryce Łacińskiej stanowił śmiertelne zagrożenie dla amerykańskiej hegemonii ${ }^{13}$.

Jak każdy błędny rycerz - nawet ten, którego Dulcyneą jest Rewolucja - Che musiał stawić czoła niezrozumieniu, osamotnieniu, a także poczuciu wyobcowania. $\mathrm{W}$ obliczu przeważających sił wroga - a zwykle i obojętności tych, których sprawy chciał bronić - nie wahał się sięgać po oręż. Jak nader trafnie ujmuje to Ryszard Kapuściński, „Niespokojna natura Guevary popycha go ciągle naprzód, ale jest to niepokój ukierunkowany, jego energia ogniskuje się na sprawie rewolucji. Całe życie Guevary to

10 Z. Bauman, Socjalizm..., s. 10, 12.

11 J. Cormier, H. Guevara Gadea, A.G. Jimenez, Che Guevara, s. 7.

12 P.J. Dosal, Comandante Che: Guerrilla Soldier, Commander, and Strategist, 1956-1967, University Park, PN 2003.

13 Ibidem, s. 302-315. 
nieustanne poszukiwanie pola walki"14. Kapuściński uwypukla strukturalne, materialne przyczyny porażki rewolucjonisty w Boliwii, wyjaśniając izolację i brak porozumienia z chłopami, tak często pojawiające się na kartach ostatniego dziennika Che. Guevara pochodził z mieszczańskiej rodziny argentyńskiej, był mówiącym po hiszpańsku białym. Miejscowi chłopi byli Indianami, mówili tylko językiem keczua i byli podejrzliwi wobec białych, ponieważ ci przez stulecia ich wyzyskiwali. Nie chcieli walczyć przeciw sprzedajnej dyktaturze prezydenta kraju, ponieważ słyszeli, ,że kiedyś prezydent przyjechał do jakiejś wioski i rozdał wszystkim buty. Buty są wielkim marzeniem tych chłopów. A cóż mogą im dać partyzanci?"'15. Na to retoryczne pytanie najlepiej odpowiada wpis Che dokonany niespełna miesiąc przed tragiczną śmiercią, odnotowujący pierwszą kąpiel po ponad pół roku'16.

Trudno nie zauważyć odległości, jaką przebył Rakowski z bydgoskiej wsi Kowalewko na warszawskie salony, gdzie królował zarówno jako wybijający się działacz polityczny, redaktor „Polityki” - wyróżniający się przystojnością, tężyzną fizyczną i smakiem kulturalnym (nie przypadkiem zapewne obie jego żony były artystkami - pierwsza skrzypaczką, druga - aktorką), czego symbolem stało się bywanie na premierach teatralnych ${ }^{17}$. Jego dzienniki przepełnione są poczuciem realizmu (chciałoby się wręcz rzec: chłopskiego rozumu, gdybyśmy nie mieli do czynienia z intelektualistą i erudytą), świadomością różnorakich ograniczeń aktywności publicznej, z których najważniejsza z jego punktu widzenia była obecność w bloku tak zwanych krajów demokracji ludowej (demoludów). Chcąc jak najwięcej zmienić w otaczającej go rzeczywistości, zreformować ją, zdawał sobie sprawę, że należy pogodzić się z tym, czego zmienić nie może. $\mathrm{Z}$ tego względu szczególnie żarliwie w oficjalnych kontaktach międzynarodowych - a rozmowy z nim lub jego artykuły publikowano w prestiżowych gazetach - zapewniał o swej miłości do Związku Radzieckiego, podczas gdy prywatnie, między innymi w dziennikach, nie sposób odnaleźć tego typu deklaracji. Wręcz przeciwnie, wśród radzieckich towarzyszy nigdy nie miał zbyt wysokich notowań - z wzajemnością. Nie sposób zasadnie oskarżać go o obłudę, raczej był gotów płacić wysoką cenę za możliwość skutecznej aktywności w danej rzeczywistości geopolitycznej. Podczas zebrań redakcyjnych „Polityki” lubił powtarzać: „Realia, panowie, realia” ${ }^{\text {. }}$. Doskonale wiedział, co, gdzie i komu może powiedzieć, a zarazem praktycznie przez cały czas starał się - mniej lub bardziej delikatnie - wybadać, czy nie sposób tych granic przesunąć choćby o parę centymetrów.

14 R. Kapuściński, Chrystus z karabinem na ramieniu, Warszawa 1975, s. 161.

15 Ibidem, s. 162.

16 Che Guevara, Dziennik z Boliwii, tłum. R. Kapuściński, Warszawa 1969, s. 306.

17 W. Władyka, Spowiedź niedokończona, „Polityka”, 27 października 2007 r.

18 M. Janicki, W. Władyka, Pierwszy i ostatni, „Polityka”, 10 listopada 2008 r. 
Warto zauważyć, że Che został uhonorowany w dziennikach Rakowskiego zwięzłym, lecz nader pochwalnym akapitem. Pisał o ,,[w]ielkiej żałobie wśród rewolucjonistów całego świata”, walce Che o wyzwolenie latynoamerykańskich chłopów „spod ekonomicznego i politycznego ucisku”, o tym, że ,[b]ył rewolucjonistą z przekonania i wrogiem wszelkich kompromisów, jednym z nielicznych idealistów na tym świecie", „,nie mógł przystosować się do życia bez walki”, podsumowując: ,„[c]złowiekiem, który już za życia był legendą"19. Znamienne, że Rakowski poświęcał wiele miejsca i pasji dokładnym analizom znanej sobie rzeczywistości, nie przejmując się zbytnio kwestiami pozbawionymi bliższego związku z sytuacją w Polsce. W tym świetle trudno zapomnieć o jednej z najsłynniejszych fraz Wesela: „Niech na całym świecie wojna, byle polska wieś zaciszna, byle polska wieś spokojna”. Inna rzecz, że ta niespotykanie spokojna, wyważona i nieskora do nieprzemyślanych kroków osoba po wielokroć dawała przykład odwagi. W 1968 roku napisał do Wiesława Gomułki: „Dość mam milczenia i przyglądania się, jak wiele moich ideałów ginie, względnie nurzanych jest w błocie. Po tym liście możecie mnie albo wyrzucić, albo pozostawić" ${ }^{20}$.

Rakowski doceniał wagę codziennego doświadczenia, a także powszechnych uczuć, takich jak duma narodowa. Mierziło go wywyższanie Sierpnia, apoteoza Solidarności, nader często odwoływał się przy tym do głosów szacownych gazet zachodnioeuropejskich i amerykańskich - wątpliwe, czy taka myśl pojawiła się u Guevary. Podkreślał rolę pozytywistycznej pracy u podstaw. Na początku lat osiemdziesiątych zwracał uwagę, że kraj, również „nasz kraj”, ocenia się w dużym stopniu przez jego zdolność do produkowania towarów niezbędnych narodowi do życia. Tymczasem Polskę utrzymywał zarówno Wschód, jak i Zachód, a jej mieszkańcy zyskują miano nierobów i żebraków ${ }^{21}$. W bardzo drobiazgowy sposób odnotowywał w dziennikach reakcje na stan wojenny, nie bez satysfakcji przytaczając opinie zamieszczane w „New York Timesie”, londyńskim „Timesie”, amerykańskim „Newsweeku” czy niemieckim „Die Zeit”. Przywoływał słowa Rudolfa Augsteina, słynnego redaktora naczelnego „Der Spiegla”: „Tragedia polska obciąża winą samych Polaków za to, co się zdarzyło”, „Polacy wielokrotnie wykazywali swoją niezdolność do inteligentnej samorządności”, „Partia komunistyczna pozostawała cierpliwa do ostatniej chwili, być może nawet zbyt długo"22.

Elementem łączącym żeglarskie opowieści Che i chłopskie opowieści Rakowskiego jest niezwykła wrażliwość i empatia, wyczulenie na wszelkie przejawy niesprawiedliwości i cierpienia, a także tęsknota do ładu opartego na ideałach wolności i równości.

19 M.F. Rakowski, Dzienniki polityczne 1967-1968, Warszawa 1999, s. 87.

$20 \quad$ Ibidem, s. 219.

21 M.F. Rakowski, Trudny dialog, Warszawa 1983, s. 11.

22 M.F. Rakowski, Dzienniki polityczne 1981-1983, Warszawa 2005, s. 159. 
W Dziennikach motocyklowych wspomina się o staruszce - astmatyczce i osobie dotkniętej niewydolnością serca, która nie była już w stanie pracować na swoje utrzymanie. W notatce pojawia się połączenie jednostkowych problemów z kwestią o zasięgu ogólnospołecznym, jeśli nie uniwersalnym, wzbogaca ją też pewna doza poetyczności. Zdaniem Che w sytuacji kobiety

można dostrzec głęboki tragizm egzystencji proletariatu na całym świecie; w tych gasnących oczach widać pokorną prośbę o wybaczenie, a często też rozpaczliwe błaganie o pociechę, które pogrąża się w pustce, tak jak niebawem ich ciało pogrąży się w niezmierzonej tajemnicy,

toteż już najwyższy czas, aby „ludzie władzy poświęcali mniej czasu na rozgłaszanie zasług własnych i swojego rządu, za to więcej pieniędzy na ogólnoużyteczne przedsięwzięcia"23.

Nie sposób wykluczyć, że najwspanialsze przykłady moralnej prawości Rakowskiego można odnaleźć w okresie zmagań, jakie prowadził przeciwko antysemickim ekscesom roku 1968. W dziennikach wprost pisał, że ,[n]ajwiększa degrengolada moralna ogarnęła moje środowisko. To, na co zdobyli się moi koledzy, jest wprost nieprawdopodobne. Demonstrowali zdolność do plucia na wszystkich i na wszystko"24.

\section{Pióro i miecz}

Pozostawiając poza polem rozważań kwestię zasadności rozróżnienia między celami i metodami, warto uwypuklić sposoby realizacji socjalistycznych dążeń, którymi przesycone są dzienniki Guevary i Rakowskiego. Należałoby dzięki temu wyeksponować i skontrastować diametralną odmienność ich wizji socjalizmu, lecz nie sposób przejść obojętnie obok elementów wspólnych, zaskakująco istotnych, może nawet ważniejszych od różnic.

Dzienniki obu autorów są świadectwem ich pasji pisarskiej, ale również i czytelniczej. Lektury stanowiły nieodłączny element ich świata, kształtowania siebie oraz kształtowania rzeczywistości wokół nich: przy czym to „wokół” oznaczało niekiedy krąg rodziny, znajomych i współpracowników, miasto, region lub kraj, a w innych przypadkach - nawet cały świat.

Dla Rakowskiego książki i prasa - a należy pamiętać, że kilkadziesiąt lat temu artykuły w opiniotwórczych gazetach i czasopismach były znacznie dłuższe niż obecnie, nieraz felietony przekraczały obszerność dzisiejszych raportów - były elementem procesu

23 E. Che Guevara, Dzienniki motocyklowe, tłum. zbiorowe, Izabelin 2005, s. 55-56.

24 M.F. Rakowski, Dzienniki polityczne 1967-1968, s. 401. 
edukowania samego siebie i innych. Jednak najbardziej charakterystycznym - i dodajmy, na wskroś socjalistycznym - rysem redaktora, a potem decydenta był niewymuszony egalitaryzm. Rakowski doskonale czuł się wśród ludzi, również tak zwanego ludu pracującego miast i wsi, z którym przez lata chętnie „pije, pali i zakąsza”25. Przywiązanie do równości czyniło go gorliwym czytelnikiem listów, na które odpowiadał - zwykle w dziennikach na koniec roku odnotowywał (liczoną w setkach) ich liczbę. Jak zauważył Daniel Passent, jego wieloletni współpracownik i przyjaciel, Rakowski jako redaktor „Polityki” „otrzymywał setki listów i na każdy odpowiadał, niektóre brał do serca, inne kazał przepisywać, oprawiać i w formie biuletynów rozsyłać do towarzyszy na górze, żeby wiedzieli, co ludzie myślą. Jeszcze inne chował do kieszeni”26. Wiara w szczerość kontaktujących się z nim ludzi dała asumpt do różnego rodzaju żartów: swego czasu otrzymał on pismo na blankiecie stadniny koni - zawiadamiano go, że postanowili nazwać nową klacz imieniem Polityka. Zapraszano redaktora do stadniny jako ojca chrzestnego, zapowiadano liczne atrakcje, w tym karetę do jego dyspozycji. Jakkolwiek list ten trafił do jego korespondencji 1 kwietnia, Rakowski potraktował go serio - dopiero w ostatniej chwili autor żartu, Jerzy Urban, nie dopuścił do wyjazdu, zbytnio obawiając się potencjalnych konsekwencji ${ }^{27}$. Urban nie bez podziwu podkreślał, że jego przyjaciel, kiedy piastował stanowisko premiera, ,marnował czas, odręcznie odpowiadając na setki listów. Nieznajomym obywatelom coś z pasją objaśniał, polemizował z ich zarzutami, gorąco przekonywał. To nie był żaden piarowski trik polityczny, tylko jego potrzeba partnerskiej rozmowy z każdym"28.

Dzienniki Che przesycone są dialektycznym napięciem między niewzruszonym szacunkiem dla każdego człowieka (wyjąwszy poniekąd możnych tego świata, lecz ta kwestia jest bardziej skomplikowana i wymagałaby pewnie odrębnej rozprawy), szczególnie zaś uciśnionych i wzgardzonych, a niewzruszonym nakazem podążania za wskazanym przezeń ideałem. Dobrze zdają się to oddawać słowa Lidii Riego uczącej pisania i czytania wiejskie dzieci i partyzantów: „Zasady wyznawane przez Che były tak twarde, że początkowo mnie onieśmielały. Później, kiedy go zobaczyłam klękającego przed zarosłymi brudem dzieciakami, o wzdętych brzuszkach, zakażonymi nosacizną, zrozumiałam, że jest wypełniony czułością"29.

$\mathrm{Z}$ jednej strony Guevara dostrzegał znaczenie swobodnej wymiany myśli, bronił choćby pisma „Pensamiento Politico”, niezależnego przeglądu marksistowskiego, które koniec końców zlikwidowano w porewolucyjnej Kubie. Bywał jednak apodyktyczny, co

25 D. Passent, MFR ma 80 lat!, „En Passant”, 1 grudnia 2006 r., http://passent.blog.polityka. pl/2006/12/01/mfr-ma-80-lat/ (11.11.2016).

26 Ibidem.

27 J. Urban, Alfabet Urbana, Warszawa 1990, s. 158.

28 J. Urban, MFR, „Nie” 2008, nr 48.

29 Cyt. za: J. Cormier, H. Guevara Gadea, A.G. Jimenez, Che Guevara, s. 205. 
niekiedy przybierało dość kuriozalne, na wpół surrealistyczne formy, kiedy na przykład żądał od swych podwładnych w Ministerstwie Przemysłu, by go krytykowali, bowiem dzięki temu może on zwiększać swą sprawność ${ }^{30}$. Inna rzecz, że swoboda ekspresji poglądów miała dla niego względną wartość - i tak Che opowiadał się za ograniczeniem wolności prasy w porewolucyjnej Kubie, uznał bowiem, że jej swobodne poczynania przyczyniły się do obalenia rządów Jacobo Arbenza Guzmána w Gwatemali31.

Jeszcze w Dziennikach motocyklowych możemy odnaleźć pewne wahania, odrobinę niepewności. Po wizycie w kopalni miedzi Chuquicamata, gdzie ujrzał nieludzkie warunki pracy, zastanawiał się, czy komunizm odmieniłby ponury los górników: „Zobaczymy, czy pewnego dnia jakiś górnik weźmie kilof i świadomie, z radością ruszy nabrać w płuca trucizny. Mówią, że tam, skąd idzie czerwony pożar, który dziś oślepia świat, jest właśnie tak, słyszałem to, ale nie wiem”32.

Zarazem jednak często nie przejmował się, czy inni są gotowi nosić brzemię, które im narzucał: pełen poświęcenia, oczekiwał od osób od siebie zależnych - w tym od rodziny, członków dowodzonych przez siebie grup oraz podwładnych urzędników ofiarności. Kiedy Guevara, niegustujący w piciu wróg hazardu, sprawował z woli Castro funkcje municypalne w Sancti Spiritus, wydał dekret zakazujący spożywania alkoholu i gier losowych. W obliczu masowych protestów musiał wycofać go już następnego dnia $^{33}$. Jego szlachetność i przyzwoitość, wyniesione do poziomu abstrakcji, oczekiwanie od podwładnych jedynie tego, czego wymagał od siebie, irytowały bardziej przyziemnych ludzi: inni nie mieli jego poczucia własnego przeznaczenia, intelektu i siły woli. Bezgranicznie oddani Che towarzysze musieli znosić jego wybuchy gniewu. Jego dobre intencje i rewolucyjny zapał nieraz tworzyły negatywnie zaskakującą mieszaninę, czego przykładem jest pomysł pracy społecznej w weekendy, między innymi przy ścinaniu trzciny cukrowej. Idea ta stała się sposobem wyzysku robotników i podwyższenia produkcji cukru: szlachetna zasada polityczna, ideologiczna i kulturowa okazała się sposobem przedłużania czasu pracy i obniżania realnych płac ${ }^{34}$.

Rakowski przez dziesiątki lat wpływał na realia Polski Ludowej nade wszystko za pomocą „Polityki”, którą kierował przez niemal ćwierć wieku (w latach 1958-1982). Tygodnik powołano do życia jako narzędzie tłumienia dążenia do głębokich zmian systemu, ale miał on również podtrzymywać kontakt ze zwolennikami żywego w pamięci Października. Nadzieje na odzyskanie suwerenności, racjonalizację ekonomiczną, pogodzenie komunizmu z ideałami wolności rozpalały w 1956 roku wyobraźnię setek ty-

30 Ibidem, s. 334.

31 J.G. Castañeda, Che Guevara, s. 153.

32 E. Che Guevara, Dzienniki motocyklowe, s. 64.

33 J. Cormier, H. Guevara Gadea, A.G. Jimenez, Che Guevara, s. 247.

34 J.G. Castañeda, Che Guevara, s. 122-123, 181-182. 
sięcy ludzi. Wszystkich, którzy nie chcieli poprzestać na eliminacji najgorszych zbrodni i absurdów rodzimego stalinizmu - skądinąd i tak stosunkowo mało jadowitego, w czym zapewne niemały udział miała niewydolność machiny biurokratycznej - określano mianem rewizjonistów. Zespół „Polityki” szybko zdominowali młodzi dziennikarze o inklinacjach rewizjonistycznych ${ }^{35}$, wierzący w system, lecz dążący do jego transformacji - podobni do młodego, zdolnego, zaledwie trzydziestodwuletniego redaktora naczelnego, członka Komitetu Centralnego Polskiej Zjednoczonej Partii Robotniczej.

„Polityka” kształtowała całe pokolenia elity, pokazując różne punkty widzenia, konsekwentnie opowiadając się za otwartością na Zachód, tolerancją i pragmatyzmem, zwalczając nacjonalizm, ksenofobię i ciasne horyzonty myślowe. Tygodnik wspierał socjalizm, lecz kładł nacisk na potrzebę reform, a zatem stanowił myślową pożywkę dla późniejszego przewrotu politycznego, stając się istotnym współtwórcą zmian, których zwieńczenie pozbawiło Rakowskiego władzy ${ }^{36}$. Kierujący „Polityką” interesował się głównie ogólnym kierunkiem pisma, jego linią, generalną wymową polityczną, co uosabiało półżartobliwe pytanie: „Na czele jakiego ruchu stoimy? ${ }^{{ }^{37}}$. Chodziło mu o socjalizm z ludzką twarzą, w którego urzeczywistnienie wierzył przez dziesięciolecia, pielęgnując złudzenia prawie do samego końca reżimu. Nigdy nie wyzbył się pewnej naiwności kontrastującej z przejawianym zwykle realizmem. We wrześniu $1980 \mathrm{roku}$, po kilkunastu dniach spędzonych na Wybrzeżu, podekscytowany Rakowski wyraził zachwyt młodymi robotnikami: „Oni są wspaniali, nieprawda? To przyszła kadra naszej partii!'”38. Miał nadzieję, że robotnicy z Solidarności odnowią PZPR, choć już wtedy nie sposób było wykluczać prawdopodobieństwa, że w ich postaci - a dokładniej w postaci ich niezaspokojonych i niezaspokajalnych w ówczesnym systemie oczekiwań, zarówno materialnych (konsumpcyjnych), jak i niematerialnych (praw i wolności obywatelskich) - ancien régime napotkał swoją Nemezis.

Guevara, w młodości wielbiciel Mahatmy Gandhiego, nigdy nie próbował wdrożyć w życie zasady biernego oporu - w rzeczywistości, której doświadczał, bliskiej w gruncie rzeczy samobójstwu - wkraczając na wojenną ścieżkę. Stał się ucieleśnieniem Christ Guérillero, Chrystusem z karabinem na ramieniu. W końcu roku 1956, niedługo przed wyprawą na Kubę, pisał z Meksyku do matki: „Jestem całkowitym przeciwieństwem Chrystusa [...] Będę walczył wszelką dostępną mi bronią, zamiast się poddać ukrzyżowaniu albo też temu, czego byś Ty sobie życzyła"’39. Guevara początkowo kierował partyzancką służbą medyczną, a zatem pozostawał wierny powołaniu lekarskiemu.

\footnotetext{
35 A. Friszke, Diariusz Rakowskiego.

36 J. Urban, Prywatka u Mieczystawa R., „Nie” 2006, nr 48.

37 D. Passent, MFR ma...

38 Zespół „Polityki”, Mieczysław F. Rakowski 1926-2008, „Polityka”, 24 listopada 2008 r.

39 Cyt. za: J. Cormier, H. Guevara Gadea, A.G. Jimenez, Che Guevara, s. 9.
} 
Jego słabości do podniosłego tonu, pod wieloma względami dorównującej poczuciu humoru, a także świadomej autokreacji zawdzięczamy dookreślenie, kiedy ostatecznie zdecydował o swym przeznaczeniu. W dziennikach odnotował sytuację godną wręcz biblijnej przypowieści:

Towarzysz tuż obok mnie upuścił dwie skrzynie: jedna zawierała amunicję, druga - środki medyczne. Poleciłem mu, by je zebrał z ziemi. Odpowiedział, że to nie jest chwila sposobna po temu, by się nimi zajmować. Niezdolny do niesienia obu skrzynek, stanąłem w obliczu dylematu: czy wziąć amunicję, czy medykamenty. Kim właściwie jestem: lekarzem czy rewolucjonistą? Wybrałem skrzynię z amunicją ${ }^{40}$.

Guevara, opierając się na swoich kubańskich doświadczeniach - wyciągając z nich jednak dość opaczne wnioski, o czym nieco dokładniej w dalszej części artykułu - wniósł istotny wkład do teorii walki partyzanckiej, choć sam postrzegał siebie nie jako teoretyka, lecz praktyka. W Kubie. Wojnie partyzanckiej (La guerra de guerillas) podkreślał znaczenie zbrojnej partyzantki jako bojowej awangardy ludu, dochodząc do wniosku, że siły ludowe mogą zwyciężyć w wojnie przeciw regularnej armii, zaś w państwach mało rozwiniętych podstawowym obszarem walki zbrojnej powinna być wieś, szczególną rolę przypisywał przy tym ognisku powstańczemu ( foco), które może stworzyć warunki rewolucyjne ${ }^{41}$. Sądzil, że rewolucją kieruje centrum militarne, a nie centrum polityczne, to drugie - czyli partia, musi być podporządkowane temu pierwszemu, czyli oddziałowi partyzanckiemu ${ }^{42}$.

Guevara, widząc na własne oczy zdradę armii gwatemalskiej, która nie dochowała wierności Arbenzowi, już w połowie lat pięćdziesiątych opowiadał się za pospolitym ruszeniem, uzbrojeniem mas pracujących. Nie mogąc walczyć z bronią w ręku, przyłączył się do grup obrony przeciwlotniczej miasta, pomagając oblężonej ludności w czasie bombardowań - właśnie wtedy trafił na listę „,niebezpiecznych komunistów” CIA ${ }^{43}$.

Che nigdy nie twierdził, że kilkudziesięciu partyzantów obali dyktatury w Ameryce Łacińskiej, nie wspominając o północnoamerykańskim imperializmie. Wierzył jednak, czemu dał wyraz w głośnym artykule opublikowanym w połowie kwietnia 1967 roku w czasopiśmie „La Tricontinental” - gdzie nawoływał do stworzenia nie jednego czy dwóch, lecz wielu Wietnamów - że grupy guérilli walczące jednocześnie na różnych frontach w Afryce, Azji i Ameryce Łacińskiej mogą zyskać taką siłę, by zmusić amerykańskie siły zbrojne do interwencji. Zaangażowane w działania na oddzielnych frontach

\footnotetext{
40 Cyt. za: ibidem, s. 127.

41 E. Che Guevara, Kuba. Wojna partyzancka, tłum. A. Paszt, Warszawa 1961, s. 15-16, 18.

42 R. Kapuściński, Od tłumacza, w: Che Guevara, Dziennik z Boliwii, s. 8.

43 J. Ławriecki, Ernesto Che Guevara, tłum. I. Bukowski, Warszawa 1986, s. 77-78.
} 
Stany Zjednoczone nie będą miały dostatecznie dużo zasobów, aby prowadzić walkę. Ugrzęźnięcie w drugim lub trzecim Wietnamie drenowałoby amerykańską gospodarkę, sprowokowało konflikty polityczne w Stanach Zjednoczonych, osłabiając amerykański naród lub jego wolę walki. Guevara wyobrażał sobie zniszczenie imperializmu jako rezultat przedłużającego się globalnego konfliktu - amerykańskich imperialistów miała zniszczyć zatem broń ekonomiczna, polityczna i militarna. Jakkolwiek Zedong i Võ Nguyên Giáp (weteran walki o wyzwolenie Wietnamu z rąk Japończyków, Francuzów i Amerykanów) mówili o niszczeniu imperializmu, nie wspominali jednak o strategii skoordynowanych sieci ognisk powstańczych wspieranych przez mocarstwa socjalistyczne dążące do unicestwienia Stanów Zjednoczonych ${ }^{44}$.

\section{Stosunek do imperiów i imperializmu}

Wydaje się, że uczciwa analizy wizji socjalizmu Guevary i Rakowskiego wymaga naświetlenia stosunku obu autorów do istniejącego w okresie pisania przez nich dzienników ładu międzynarodowego, ze szczególnym uwzględnieniem relacji między światem kapitalistycznym, socjalistycznym (komunistycznym) i tak zwanym Trzecim Światem. Wszelkie idee i ideały, jeśli nie są domeną kawiarnianych teoretyków lub uczonych żyjących w wieży z kości słoniowej, muszą konfrontować się z rzeczywistością. W sytuacji, kiedy byt nie nadąża za powinnością, a próby wcielenia w życie najbardziej szczytnych wartości dają więcej niż wątpliwe rezultaty, istotna staje się konceptualizacja tego rozdźwięku dająca odpowiedź na wiele pytań, które w innym przypadku pozostałyby w sferze jałowych dywagacji.

Jakkolwiek imperializm w nowoczesnym wcieleniu przeżywał swoje apogeum w ostatnich dekadach XIX i pierwszych dekadach XX wieku, to w okresie powojennym bynajmniej nie zanikł, uległ jedynie daleko idącej transformacji. Natura tego przekształcenia nawet obecnie nie jest oczywista dla badaczy, szczególnie z kręgów marksistowskich. Wiele skorzystaliby oni, gdyby - wzorem Włodzimierza Iljicza Lenina - sięgnęli do klasyka, liberała Johna A. Hobsona, który już w 1901 roku pisał o socjalistycznych zwolennikach imperializmu (wtedy - brytyjskiego) ${ }^{45}$. Rygorystyczna i pogłębiona analiza powinna uświadomić im, że nie ma żadnych przedustanowionych powodów wykluczających istnienie niekapitalistycznych imperiów.

Abstrahując od debaty, czy i jak nowoczesne imperia są podobne do wcześniejszych, należy zauważyć, że od kilkuset lat kluczowe znaczenie odgrywają imperia kapitalistyczne. Nie oznacza to jednak braku imperiów, które nie kierowały się logiką prywatnej akumulacji kapitału, lecz nawet najpotężniejsze z nich - jak Związek Radziecki

44 P.J. Dosal, Comandante Che:..., s. 314-315.

45 J.A. Hobson, Socialistic Imperialism, „International Journal of Ethics” 1901, vol. 12. 
- działały w otoczeniu międzynarodowym dostosowanym lub dostosowującym się do systemu kapitalistycznego. Nie bez powodu hasłem stalinowskiej industrializacji było „dogonienie i przegonienie Zachodu”. Warto pamiętać, że sztandarowym projektem pierwszego planu pięcioletniego było stworzenie Magnitogorska jako - w zamyśle twórców - większej i lepszej kopii miasta Gary w stanie Indiana, wtedy czołowego ośrodka produkcji stali na świecie, w co zaangażowano amerykańskich inżynierów i wytrawnego niemieckiego architekta i planistę Ernsta Maya ${ }^{46}$.

W gruncie rzeczy nie sposób oddzielić historycznego rozwoju kapitalizmu od ekspansji imperialnej - ten pierwszy przetrwał, przenosząc swe potworności i ofiary do niższych klas robotniczych u siebie i eksportując je do peryferyjnych regionów Trzeciego Świata ${ }^{47}$. Doskonale zdawali sobie z tego sprawę wybitni myśliciele liberalni - i tak Alexis de Tocqueville, członek Akademii Nauk Moralnych i Politycznych, przez dziesiątki lat wzywał do kolonizacji Algierii, by poprawić stan francuskich finansów. Zalecał stosowanie wszelkich dostępnych środków, aby spacyfikować bunt Algierczyków, włącznie z eksterminacją, „chwytaniem bezbronnych mężczyzn, kobiet i dzieci", paleniem wsi i niszczeniem zbiorów ${ }^{48}$.

Che, zwolennik marksizmu-leninizmu, podzielał opinię Lenina o imperializmie jako najwyższym stadium kapitalizmu. Już w młodości mógł się naocznie przekonać, jak drapieżne formy przybiera ekspansja amerykańskiego kapitału, stąd też - w kontekście Chile, lecz tę obserwację można rozciągnąć na cały region - uznał, że państwo to czeka teraz „największy wysiłek”, a mianowicie

pozbycie się niewygodnego jankeskiego przyjaciela, co będzie w najbliższym czasie ogromnym zadaniem, biorąc pod uwagę wielkość inwestycji amerykańskich w kraju, oraz łatwość, z jaką Stany Zjednoczone mogą wywrzeć ekonomiczną presję na Chile, gdy tylko poczują, że ich interesy są zagrożone ${ }^{49}$.

Dwadzieścia lat później, kiedy wspierany przez CIA generał Augusto Pinochet obalał demokratycznie wybrany rząd Salvadora Allende, słowa te nabrały złowieszczej aktualności i trafności.

Warto nadmienić, że Che $\mathrm{w}$ trakcie wymuszonego okolicznościami pobytu w Miami poznał wszechpotęgę dolara, nazywając wszystkich Amerykanów Billami,

46 L. Graham, The Ghost of the Executed Engineer: Technology and the Fall of the Soviet Union, Cambridge, MA 1993, s. 57.

47 Choose Peace. A Dialogue between Johan Galtung and Daisaku Ikeda, London-Chicago, IL 1995, s. 45 .

48 Cyt. za: O. Le Cour Grandmaison, Kolonizować - eksterminować. O wojnie i państwie kolonialnym, „Lewą Nogą” 2005, nr 15, s. 284-285.

49 E. Che Guevara, Dzienniki motocyklowe, s. 76. 
bowiem ich świat kręcił się wokół dollar bills, czyli banknotów dolarowych. Uważał ich za duże dzieci wyznające religię dolara i pozbawione politycznej świadomości. Wydaje się, że nie żywił nienawiści do narodu amerykańskiego, lecz wrogo odnosił się do jego przywódców politycznych i przemysłowców ${ }^{50}$. Ich decyzje narzucały krajom Ameryki Łacińskiej brzemię uniemożliwiające rozwój, skazując je tym samym na - jak trafnie ujął to Andre Gunder Franka - rozwój niedorozwoju ${ }^{51}$.

Niekiedy innym, choćby jego wieloletniemu przyjacielowi i towarzyszowi broni Fidelowi, udawało się nieco okiełznać jego antyimperialistyczny żar. Ostrożnie wypowiadał się o Stanach Zjednoczonych choćby na forum Komisji Ekonomicznej dla Ameryki Łacińskiej ONZ (CEPAL), zwłaszcza - ironicznie zauważa Jorge G. Castañeda -

biorąc pod uwagę oczekiwania rozbudzone przez prasę międzynarodową. Niektórzy obserwatorzy niemal spodziewali się, że Che Guevara po prostu skosi delegatów ze swojego karabinu maszynowego; mieli nadzieję, że będzie nawoływał do powstania w całej Ameryce i przeklinał dzień narodzin Stanów Zjednoczonych ${ }^{52}$.

Opinie wygłaszane na kilka dni przed inwazją w Zatoce Świń w kwietniu 1961 roku - ówcześnie szkolił milicję ludową, która w największym stopniu przyczyniła się do klęski agresji - były bardziej jednoznaczne: Ameryka to „nowi naziści świata”, którzy „nie mają nawet tragicznej wielkości niemieckich generałów, którzy wciągnęli całą Europę w najgorszy Holocaust w dziejach świata i pogrzebali siebie samych w apokaliptycznej katastrofie. Ci nowi naziści, tchórzliwi kłamcy i oszuści [...] zostali pokonani przez historię" 53 .

Stosunek Guevary do kontrolowanego przez ZSRR bloku państw socjalistycznych ewoluował - zrobił wszystko, aby porewolucyjna Kuba dołączyła do ich grona (co nie było od początku przesądzone), potem jednak wielokrotnie wyrzucał im, że niedostatecznie wspierają Trzeci Świat w walce z kapitalistycznym imperializmem. Jego zdaniem pomoc nie tylko służy interesom demoludów, lecz stanowi obowiązek - sfinansowanie rozwoju biednych krajów „wkraczających na drogę wyzwolenia” powinno być zadośćuczynieniem za ich ogromną ofiarę. Żywił nieskrywaną - i szczególnie szokującą towarzyszy radzieckich przywykłych do odgrywania roli wielkiego brata - wrogość wobec koncepcji pokojowego współistnienia antytetycznych systemów, rozwijania stosunków gospodarczych, kulturalnych czy politycznych. Szczególnie oburzał go „niemoralny charakter" wymiany handlowej między krajami socjalistycznymi i Trzeciego Świata:

\footnotetext{
50 J. Cormier, H. Guevara Gadea, A.G. Jimenez, Che Guevara, s. 69.

51 A.G. Frank, The Development of Underdevelopment, „Monthly Review” 1966, vol. 18.

52 J.G. Castañeda, Che Guevara, s. 197.

53 Cyt. za: ibidem (przyp. *).
} 
„Jak można mówić o «wzajemnych korzyściach», kiedy po tych samych światowych cenach, po których sprzedawane są surowce wydobywane w pocie czoła w biednych krajach, sprzedawane są maszyny i urządzenia produkowane w nowoczesnych, zautomatyzowanych fabrykach?”; „Kraje socjalistyczne mają moralny obowiązek zakończyć milczącą współpracę z żyjącymi z wyzysku krajami Zachodu"s4. Guevara podkreślał, że dążący ze swej istoty do dominacji nad innymi ludami imperializm może zostać zniszczony jedynie dzięki wspólnemu, powszechnemu wysiłkowi i poświęceniu, przestrzegał również przed lekceważeniem jego najnowszego wcielenia - neokolonializmu ${ }^{55}$.

Latynoamerykański guérillero wiele nadziei wiązał z chińskim mocarstwem, w którym jeszcze nie wygasł rewolucyjny żar. O uwielbieniu dla Chin dobitnie świadczy fakt, iż Che własną córkę nazywał „swym maleńkim Mao”, a w okresie inwazji w Zatoce Świń jego grupę bojową określano mianem los Mao Mao. Warto wspomnieć znamienną sytuację, która wydarzyła się podczas wizyty Guevary w Chinach. W trakcie obiadu wydanego na cześć Zedonga na sali pojawił się noszący tylko barwną przepaskę olbrzym prowadzący na smyczy podskakującą małpkę, której w pewnym momencie ściął szablą wierzch czaszki, aby poczęstować gościa jej móżdżkiem. Che po powrocie do hotelu wyraził uznanie dla precyzji ciosu ${ }^{56}$. Wydaje się, że gdyby podobnie krwawe przedstawienie zainscenizowano w Stanach Zjednoczonych, dla Guevary stałoby się to kolejnym argumentem potwierdzającym zdziczenie późnego kapitalizmu.

Sytuacja Europy Środkowej, w tym Polski, była poniekąd lustrzanym odbiciem realiów Ameryki Południowej, choć dominacja imperium radzieckiego miała charakter mniej wyrafinowany, często wręcz toporny. Inna rzecz, że ojczyzna wszystkich komunistów, w odróżnieniu od ojczyzny coca-coli i mitu kariery od pucybuta do milionera, nie miała takiej mocy przyciągania, soft power. Mówiąc krótko: Związek Radziecki był nieraz biedniejszy i mniej atrakcyjny od państw, które zdominował. Nie przypadkiem w połowie lat sześćdziesiątych Rakowski w trakcie pierwszego spotkania z młodym wysłannikiem „Le Monde”, Bernardem Marguerittem, wyznał, że zaraz po wojnie znalazł się „, kraju rządzonym przez komunistów i kontrolowanym przez Sowietów”; jedyne, co można było zrobić „,w tych warunkach tragicznych” dla kraju, to zapisać się do PZPR, gdyż mimo wszystko nadal było to państwo polskie ${ }^{57}$.

Co ciekawe, gdyby Guevara spróbował przyjrzeć się Boliwii nieco bliżej, spojrzeć na nią chłodnym okiem - a choćby przypomniał sobie zawołanie Patria o muerte!, którym zagrzewał do walki towarzyszy rewolucji kubańskiej - musiałby odnaleźć wiele analogii ze środkowoeuropejskimi demoludami. Jednak nie zwracał on uwagi na

\footnotetext{
54 Cyt. za: R.G. Kania, Che Guevara - misjonarz rewolucji, Warszawa 2004, s. 266.

55 Ibidem, s. 267.

56 J. Cormier, H. Guevara Gadea, A.G. Jimenez, Che Guevara, s. 307-308.

57 Zespół „Polityki”, Mieczysław F. Rakowski...
} 
złożoność życia politycznego i kultury boliwijskiej, uznając Boliwię za typową republikę bananową zamieszkaną przez czekającą na wyzwolenie ludność, nie doceniając roli nacjonalizmu przenikającego zwłaszcza armię. Zlekceważył przestrogi Mario Monje, przywódcy boliwijskiej partii komunistycznej, który trzeźwo stwierdził, że „kiedy ludzie dowiedzą się, że na czele tego ruchu partyzanckiego stoi obcokrajowiec, odwrócą się do was plecami i odmówią wam poparcia”, „zginiecie bohatersko, ale nie macie żadnych szans na zwycięstwo"s8.

Pod koniec lipca 1968 roku Rakowski zanotował z rezygnacją, że „[b]rutalny nacisk ZSRR i kilku jego sprzymierzeńców stawia w innym świetle powszechnie używane dotychczas pojęcia, a wśród nich suwerenność i prawo każdego narodu do samostanowienia", a ,[n]aga i brutalna siła staje się rozstrzygającą racją w stosunkach między krajami socjalistycznymi”’59. Przy tej okazji piętnował artykuł w „Prawdzie” pióra znanego mu „z władczego tonu i zarozumialstwa Jurija Żukowa, nadwornego komentatora tej niby-gazety". Autor wystąpił jako krytyk socjalizmu demokratycznego. Żukow „łże jak najęty”, pisząc, że na Zachodzie właśnie wynaleziono „nowe modele” socjalizmu, choć de facto „terminu tego od lat powszechnie używają niemieccy socjaldemokraci". Kłamstwo posłużyło Żukowowi do wysnucia wniosku, że „niektórzy ludzie w Pradze weszli na cudzą ścieżkę”. Artykuł stanowił część ideologicznej kampanii „,prowadzonej od pewnego czasu przeciwko CSRS”“60.

Dzienniki polityczne Rakowskiego pokazują, że dużo lepiej czuł się on w towarzystwie zachodnich socjaldemokratów - Willy'ego Brandta czy Olofa Palmego - niż radzieckich, jak nie bez widocznej pogardy określał polityków ZSRR. Z nimi prowadził najszczersze rozmowy, z ich opinią się liczył, choć reprezentowali oni państwa kapitalistyczne. Od nich dowiadywał się niezwykle interesujących rzeczy. W latach siedemdziesiątych pewien niemiecki socjaldemokrata wyznał mu, że większość posłów SPD średniego pokolenia nie ma nic wspólnego ani z socjalizmem, ani z klasą robotniczą. Innymi słowy - wśród zachodnich kadr politycznych można było odnotować podobną bezideowość, co wśród kadr politycznych demoludów. Niemiecki rozmówca wspomniał też o swej wymianie poglądów na wolność prasy z Nikitą Chruszczowem. Przywódca radziecki miał na ten temat wyrobioną opinię: „Wolność prasy? - zapytał. - Po to, żeby wydrukowali kłamstwa? To ja już wolę sam kłamać’’1.

Dzienniki Rakowskiego doskonale ilustrują słynną tezę Immanuela Wallersteina, według którego podczas zimnej wojny w gruncie rzeczy żadne z supermocarstw, wbrew konfrontacyjnej retoryce i wojowniczym rytuałom, nie było zainteresowane zmianą status quo, nawet jeśli za rewizją istniejącego układu sił dobrowolnie opowiadało się dane

\footnotetext{
58 J.G. Castañeda, Che Guevara, s. 331, 335.

59 M.F. Rakowski, Dzienniki polityczne 1967-1968, s. 326.

$60 \quad$ Ibidem, s. 326-327.

${ }^{61}$ M.F. Rakowski, Dzienniki polityczne 1972-1975, Warszawa 2002, s. 44.
} 
społeczeństwo. Wolność słowa w demoludach ograniczano nie tylko w imię oficjalnej ideologii marksizmu-leninizmu, ale i podtrzymywania poprawnych relacji z Zachodem. Rakowski w latach siedemdziesiątych musiał zrezygnować z przygotowania audycji telewizyjnej o zbliżających się we Francji wyborach, bowiem jakiś czas wcześniej trzeci sekretarz ambasady francuskiej zadzwonił gdzieś ze skargą, że w polskiej telewizji krytykuje się prezydenta V Republiki Georges'a Pompidou. Kierujący Radiokomitetem Maciej Szczepański powiedział wprost, że władze PRL są zainteresowane, by prawicowy prezydent pozostał u władzy. Szef „Polityki” uznał, że Szczepański wyznał to, co radzieccy i polscy liderzy mówią w skrytości - w ich interesie nie leżą żadne lewicowe zmiany polityczne na Zachodzie, gdyż demoludy w dużej mierze „utrzymują się dzięki ustawicznej antykapitalistycznej propagandzie. Co by się stało, gdyby nagle wróg zniknął, a na jego miejsce pojawili się autentyczni sojusznicy, nie skorzy jednak do podziwiania niezliczonych głupstw, jakie popełniamy?" ${ }^{2}$.

Dodajmy, że kapitalistyczny straszak miał też odwrócić uwagę od niewydolności systemu, braku towarów, zapaści służby zdrowia, ,przyjaznych stosunków między narodami ZSRR". Wyrazem tych ostatnich była opowieść o Rosjaninie, któremu na Łotwie, kiedy pytał o drogę, zawsze wskazywano zły kierunek: „Zastanawiałem się, dlaczego? I wreszcie przypomniałem sobie, że przecież wyzwoliliśmy ich w 1945 roku”. „Przodujący kraj socjalizmu” to „kolos, który samym swoim istnieniem” podtrzymuje stan rzeczy, w którym intelektualna miernota sprzyja karierze, zaś ludźmi mądrymi się pogardza ${ }^{63}$.

Błędem byłoby mniemać, że Rakowski wyrażał się krytycznie wyłącznie o imperium radzieckim. Gniewało go, że cenzura nie pozwoliła pisać „Polityce” o klęsce Amerykanów w Wietnamie Południowym, co stało się okazją do konstatacji, że Polską Ludową rządzą „mali gracze, bawiący się w rządzenie 34-milionowym państwem. Są wyzuci z ideologii, traktują ją jako środek pozwalający kontrolować społeczeństwo". Podkreślał, że ZSRR obawia się wzrostu znaczenia Chin, próbuje też ustanowić sojusz z USA, ale podobne kalkulacje nie dotyczą PRL: „Nasze milczenie przyjmowane jest z pogardą. Przez 15 lat mobilizowaliśmy naród do walki przeciwko imperialistom amerykańskim, a teraz zachowujemy się tak, jakby Pan Bóg odebrał nam mowę"64.

Zauważmy też, że Rakowski podczas pobytu na Kubie poprosił gospodarzy, by zawieźli go do Zatoki Świń, „tam, gdzie Amerykanie wysadzili w 1961 roku desant, złożony głównie z emigrantów kubańskich, którzy mieli obalić rzekomo chwiejący się reżim Castra. Skończyło się sromotną porażką i upokarzającym widowiskiem, procesem przeciwko desantowcom. Przyjemnie było wrócić do przeszłości’”55.

\footnotetext{
62 Ibidem, s. 97.

63 Ibidem, s. 199, 337.

${ }^{64}$ Ibidem, s. 335-336.

65 M.F. Rakowski, Dzienniki polityczne 1984-1986, Warszawa 2005, s. 142-143.
} 


\section{Dwa charaktery, dwa socjalizmy?}

Historycznie rzecz ujmując, charakter to etyczna wartość, której podporządkowane są nasze pragnienia i stosunki z innymi. Horacy uważa, że charakter człowieka zależy od jego powiązań ze światem. To pojęcie szersze niż dzisiejsza „osobowość”, na którą składają się uczucia i pragnienia rodzące się we wnętrzu człowieka, które mogą zatem pozostać niezauważone przez innych. Charakter to długotrwały wymiar naszych doświadczeń emocjonalnych. Jak pisze Richard Sennett,

[z] nieustannego mętliku uczuć, jaki jest udziałem każdego z nas, wybieramy i staramy się zachować niektóre na dłużej; one właśnie będą budować nasz charakter. Charakter określa więc te spośród naszych cech, które w sobie cenimy i które inni mają w nas cenić6 ${ }^{6}$.

Warto zatem, podsumowując powyższy wywód, spróbować określić, jaki charakter odpowiada socjalistycznej wizji obu autorów.

Guevara żądał niemożliwego - stworzenia nowego człowieka, hombre nuovo, odrzucającego osobistą korzyść jako zasadę organizacji relacji międzyludzkich i międzynarodowych. Hombre nuovo, pełen nieustannej gotowości poświęcania się altruista wyzbyty egoistycznego indywidualizmu i pragnący powszechnego braterstwa, dziwnie przypominał swą żarliwością i niezachwianymi przekonaniami pierwszych chrześcijan. Tylko zniesienie wyzysku człowieka przez człowieka miało przybliżyć nastanie królestwa wolności, wdrożenie w życie socjalizmu ${ }^{67}$.

Konieczny jest osobisty przykład, włącznie ze złożeniem ofiary z własnego życia, stąd też boliwijska misja - to pojęcie o religijnym zabarwieniu wydaje się najbardziej adekwatne - rewolucjonisty uderzająco przywodzi na myśl Golgotę. Dziennik z Boliwii, przynajmniej w ostatnich sześciu miesiącach, zauważa tłumaczący go na język polski Kapuściński, to notatnik człowieka, który prowadzi walkę beznadziejną, choć mógłby się ocalić, składając broń, jednak

idzie dalej, upada, podnosi się i idzie dalej; ostatnich stron Dziennika nie rozjaśnia już żadna nadzieja, obręcz zaciska się coraz bardziej, widzi, jak giną jego ludzie, widzi, jak uciekają, jest coraz bardziej sam, dławiony astmą, przygniatany ciężarem ogromnego plecaka, w którym jest pełno książek, zagłodzony ${ }^{68}$.

66 R. Sennett, Korozja charakteru. Osobiste konsekwencje pracy w nowym kapitalizmie, tłum. J. Dzierzgowski, Ł. Mikołajewski, Warszawa 2006, s. 8, 9.

67 R.G. Kania, Che Guevara..., s. 265-266; J. Cormier, H. Guevara Gadea, A.G. Jimenez, Che Guevara, s. 331-332.

68 R. Kapuściński, Od ttumacza, s. 6. 
Chrystus, kiedy go pojmano w ogrodzie Getsemani, kazał Szymonowi Piotrowi schować miecz do pochwy, gdy apostoł zaatakował sługę arcykapłana. Che, który oświadczył w przemówieniu wygłoszonym w Santa Clara w 1965 roku, iż ,[h]umanizm rodzi się w lufie działa", jak pokazują liczne notatki, w Boliwii okazywał szlachetność i litość, co tylko przyśpieszyło rozbicie jego oddziału: „przyjechała ciężarówka wojskowa, ta sama co wczoraj, z dwoma owiniętymi w koce żołnierzykami na ławce wozu. Nie miałem serca strzelać do nich i mój mózg nie pracował dostatecznie szybko, żeby ich zatrzymać, pozwoliliśmy im przejechać”; „[m]ieliśmy zamiar zastrzelić ich, ale postanowiliśmy puścić ich wolno"69. Dopełnieniem mitu Christ Guérillero było znalezienie w jego plecaku fragmentu wiersza Leona Felipe dotyczącego przemyśleń Che na temat przeznaczenia i czekającej go śmierci (w tym miłości do Jezusa i grzesznych ludzi), a także pośmiertne fizyczne podobieństwo do utrwalonych wizerunków Ukrzyżowanego symbolizowane przez słynne zdjęcie Freddy'ego Alborty. Zabity rewolucjonista zmartwychwstał jako „Chrystus z Vallegrande, a w jego przejrzystych, otwartych oczach malował się delikatny spokój zgody na ofiarę"70.

Guevara podkreślał znaczenie „uczucia głębokiej miłości”, „miłości do ludu”, wskazując na potrzebę ,wielkiej dawki skromności, głębokiego poczucia sprawiedliwości i szczerego przywiązania do prawdy”, dzięki którym można uniknąć ,zasklepienia się w skrajnych dogmatach, zimnej scholastyce" 71 . Jednak graniczące z narcyzmem przekonanie o własnej nieomylności, wzmacniane gotowością do poświęcenia i czynienia dobra, najczęściej wykluczały wahania. Pewien francuski ekonomista, który go znał, trafnie zauważył, że Che zbyt pośpiesznie chciał podążać do wyznaczonego celu, wymóc na innych, by postępowali w myśl jego pouczeń. Nie interesował go dialog i rozmowa ani też dawanie ludziom wyboru i czasu, by podjęli decyzję ${ }^{72}$. Nie miał też wątpliwości tam, gdzie zapewne powinny się one pojawiać - w imię wyznawanych idei gotów był nie tylko umrzeć, ale też zabijać, o czym nie zapomnieli jego wrogowie ${ }^{73}$. Nadzorował egzekucje, bezpośrednio lub ze swojego okna, kilkuset współpracowników obalonego dyktatora Kuby, które zatwierdził własnym podpisem. Inspirował nasilenie represji porewolucyjnych, zakładając pierwszy obóz pracy w Guanahacabibes, inicjując odrażającą praktykę więzienia dysydentów i homoseksualistów (potem - chorych na AIDS), czyli - jak sam wyjaśniał - ludzi popełniających ,przestępstwa przeciw rewolucyjnej moralności, czemu towarzyszą inne sankcje, jak usunięcie z pracy, a w innych

69 Cyt. za: L. Stomma, Recenzja, „Che Guevara-Dziennik z Boliwii”, „Che-klęska i zwycięstwo”, „Tygodnik Powszechny” 1970, nr 18, http://kapuscinski.info/recenzjache-guevara-dziennikz-boliwii-che-kleska-i-zwyciestwo.html (11.11.2016).

70 J.G. Castañeda, Che Guevara, s. 11.

71 Cyt. za: J. Cormier, H. Guevara Gadea, A.G. Jimenez, Che Guevara, s. 345.

72 Ibidem, s. 329.

73 P.J. Dosal, Comandante Che..., s. 315. 
przypadkach nie tyle same sankcje, ile reedukacja przez pracę. To jest ciężka praca, raczej warunki pracy są ciężkie, ale nie są straszne" "74.

Guevara widział tylko to, co chciał widzieć, stąd też nie dostrzegał podczas wizyt w bratnich krajach sklepów dla nomenklatury czy prostytutek hotelowych ${ }^{75}$. Nie dostrzegł, że zwycięstwo rewolucji na Kubie wymagało nie tylko talentów artysty partyzantki, jak określano niekiedy Che, ale i zdolności politycznych Fidela. Umniejszał ogromną pracę setek działaczy miejskiego podziemia - często wywodzących się z klasy średniej-którzy się narażali, a niekiedy tracili życie, by umożliwić mu prowadzenie walki ${ }^{76}$.

Traktowanie polityki, szerzej: działalności publicznej, jako gry, sztuki dyplomacji i różnych wybiegów, obce rewolucyjnym inklinacjom Guevary, stanowiło niezmiernie trwały element aktywności Rakowskiego. Dzienniki polityczne to niezwykły zapis uporczywych starań człowieka - człowieka ideowego i otwartego na świat, zawsze gotowego, żeby się uczyć i dzielić zdobytą wiedzą - o zdobycie wpływu na rzeczywistość. Starań, w których - co skądinąd wiadomo - trudno doszukać się żądzy zysku i sławy. Rakowski był ostrożny, gotowy - w imię wyższego celu - na trudne kompromisy. Dokonywał rzeczy, które nawet w jego własnych oczach chwały mu nie przynosiły, lecz w danej sytuacji wydawały się konieczne, a przynajmniej - przydatne. Wiedział, że niekiedy siła argumentów musi ustąpić przed argumentem siły. Oczywiście, to niesprawiedliwe, jednak - jak czytamy w Osiemnastym Brumaire'a Ludwika Bonaparte "[1]udzie sami tworzą swoją historię, ale nie tworzą jej dowolnie w wybranych przez siebie okolicznościach, lecz w takich, w jakich się bezpośrednio znaleźli, jakie zostały im dane i przekazane" ${ }^{\prime 7}$. Należy jednak upatrywać w tym nadziei: pomimo wszelkiego rodzaju katastrof i tragedii, takich jak zdławienie praskiej wiosny czy wprowadzenie w Polsce stanu wojennego, życie toczy się dalej - przeszłości nie sposób zmienić. Zawsze, nawet w najbardziej ponurej sytuacji, można zrobić coś dobrego, choć trochę poprawić los konkretnej osoby - Rakowski znany był z tego typu interwencji, choć często ludzie, którym pomagał, nie żywili bynajmniej wobec niego wdzięczności a także całego społeczeństwa. Niezwykle ważne, że pomimo kilkudziesięciu lat tkwienia w kręgu władzy systemu, gdzie obłudę i bezideowość ceniono na równi ze służalstwem i tępotą, Rakowski zdawał się nie tracić światopoglądu socjalistycznego. W połowie lat osiemdziesiątych, podczas podróży do Ameryki Łacińskiej, pisał o „niezapomnianym przeżyciu", jakim było oglądanie rewolucji sandinistów w Nikaragui. Rewolucji kierowanej przez marksistów, ale i księży związanych z teologią wyzwolenia:

74 J.G. Castañeda, Che Guevara, s. 141-142, 173.

75 Ibidem, s. 175.

76 Zob. J.E. Sweig, Inside the Cuban Revolution: Fidel Castro and the Urban Underground, Cambridge, MA 2004.

77 K. Marks, Osiemnasty Brumaire'a Ludwika Bonaparte, Warszawa 1949, s. 14. 
Ich udział w rewolucji jest zrozumiały. Chcą być z ludem żyjącym w nędzy i beznadziei. Uważają się za uczniów Chrystusa, który żył wśród biednych i im, a nie bogaczom, obiecywał Królestwo Niebieskie. Tu, w Nikaragui, zrozumiałem, dlaczego są zwalczani przez Watykan. To proste, jak wzorzec metra. Są to prawdziwi obrońcy ludu bożego. Nie mieszkają w pałacach, nie stroją się w iskrzące złotem ornaty! Są Kościołem ubogich ${ }^{78}$.

Nie przeszkodziło mu to jednak wprowadzić kilka lat później czysto neoliberalne, nomen omen wilczo kapitalistyczne przemiany. Doprowadził też do uchwalenia ustawy o stosunku państwa do Kościoła katolickiego w PRL nie tylko sprzecznej z obowiązującą konstytucją, ale stawiającej tę instytucję w uprzywilejowanej, zwłaszcza ekonomicznie, sytuacji. Tym razem poczucie realizmu nakazujące obłaskawić Kościół przed zbliżającymi się wyborami 4 czerwca 1989 roku, by poprawić własne notowania, całkowicie go zawiodło. Stało się też precedensem w późniejszych relacjach lewicy z tą instytucją.

\section{Podsumowanie}

Nie sposób również zapominać, że obaj omawiani powyżej autorzy koniec końców przegrali. Rakowski jest wspominany przez skrajnie wolnorynkowy biznes jako premier, który oddał tekę ministra przemysłu przedsiębiorcy Mieczysławowi Wilczkowi, który skutecznie wdrożył ultraliberalną ustawę o prowadzeniu działalności gospodarczej (zwaną ustawą Wilczka). Rewolucja kubańska, o którą walczył Che, jak wszystko na to wskazuje, okaże się swoistym interludium w kapitalistycznych dziejach Kuby (choć nomenklatura komunistyczna zapewne wzbogaci się dzięki przywróceniu systemu rządów kapitału). Dziś Che to postać rodem z „,radykalnych” nisz rynkowych, przemysłu produkcji koszulek, a także zegarków marki Swatch z jego podobizną, flagą Kuby i napisem Revolution ${ }^{79}$.

Wizja socjalizmu Guevary (komunizmu, leninowskiej wersji socjalizmu, ideologii i praktyki drogi na skróty) ${ }^{80}$ i Rakowskiego (socjaldemokracji, czyli socjalizmu demokratycznego) obrazuje stuletni podział na lewicy, który skutecznie się przyczynił do wykrzywienia, doprowadzenia do tragicznego absurdu lub unicestwienia postępowych dążeń. Stanowi również cenne źródło inspiracji - gwoli ścisłości: inspiracji i przestrogi - dla osób pragnących wcielać w życie idee socjalizmu jako utopii w działaniu: utopii bez celu, ale z wyznaczonym kierunkiem.

\footnotetext{
78 M.F. Rakowski, Dzienniki polityczne 1984-1986, s. 140.

79 Swatch, To Che, https://www.swatch.com/en/watches/gj115-to-che/ (11.11.2016).

80 Z. Bauman, Socjalizm..., s. 191.
} 


\title{
CAUTIOUS AND ROMANTIC? VISION OF SOCIALISM IN ERNESTO CHE GUEVARA'S AND MIECZYSŁAW F. RAKOWSKI'S DIARIES
}

\begin{abstract}
Summary
The aim of this article is to analyze two visions of socialism, one - revolutionary (epitomized by the Ernesto Che Guevara), second - reformist (epitomized by the Polish journalist and politician Mieczysław F. Rakowski). Paper contains four chapters. Firstly, author compares both persons to main characters of the famous Cervantes book, Don Quixote and Sancho Panza. Second part is focused on the key ways of fighting - armed resistance to capitalism in the case of Che and peaceful work within 'real socialism' in the case of Rakowski. Then article describes Che's and Rakowski's relationships with empires and imperialisms, not only capitalist - like the United States, but also socialist - Soviet Union. Last chapter is devoted to the characters of the both socialist - radical socialist Guevara and pragmatist socialist Rakowski.
\end{abstract}

Keywords: Ernesto Che Guevara, Mieczysław F. Rakowski, socialism, imperialism, revolution 